\title{
Qualitative and Quantitative Impact of Honeybee Pollination on Apple Production in Shimla Hills of Himachal Pradesh, India
}

\author{
V. K. Mattu ${ }^{1}$, Dimpal Nirala ${ }^{2}$ \\ Sociobiology and Behavioural Ecology Research Lab. \\ Department of Biosciences, Himachal Pradesh University, Shimla-171 005 (HP), India
}

\begin{abstract}
The experiment on quantitative and qualitative effects of honeybee pollination on apple crop were carried out on European bee Apis mellifera L. and Indian hive bee Apis cerana F., by placing two colonies of each species in experimental apple orchards located at Padola (2200 m), Kalzar (2514 m) and Jarol (2648 m) areas in Shimla hills of Himachal Pradesh. There was no significant difference $(P>0.01)$ in the fruit set in different experimental designs (honeybees pollinated flowers, open pollinated flowers and in control) in selfcompatible varieties of apple (Golden Delicious and Red Gold), but the differences in these experimental designs were significant $(P<0.01)$ in self- incompatible varieties like Royal Delicious and Red Delicious. There was some difference in the fruit drops of selfincompatible varieties between open and honeybees pollinated flowers but it was not significant (P>0.01). In Golden Delicious and Red Gold, the qualitative pollination data showed that weight, length, breadth, volume and number of seeds per fruit developed were significantly maximum in honeybee pollinated flowers $(P<0.01)$ and minimum in fruits developed under control experimental conditions in all the three orchards. Whereas, in Royal Delicious and Red Delicious varieties, the weight, length, breadth, volume and number of seeds per fruit were significantly more $(P<0.01)$ in fruits developed from honeybees pollinated flowers than in fruits from open pollinated flowers.
\end{abstract}

Keywords: Honeybee pollination, quantitative and qualitative effects, apple crop, Shimla hill

\section{Introduction}

Honeybees and flowering plants are dependent upon each other for their existence. Most of the plants are dependent on insects for their pollination requirements, whereas, insects in turn depend upon plants for energy to maintain their activities (Seeley, 1985). This energy relationship between plants and nectar gathering insects is the necessary basis for studying the crop pollination, honey production and their foraging strategies (Morse, 1976; Akaratanakul, 1987). Bees and certain flowering plants have, therefore, evolved a well adjusted system of interdependence, which is very important in the process of their organic evolution (Deodikar, 1962; Martin, 1992).

Apple (Malus domestica) is one of the most important fruit crops globally with 2010 production across 93 countries worth US\$ 64bn (FAOStat, 2013). Apple cultivars are selfincompatible to varying extents and require pollen transfer from polliniser cultivar to set fruit in marketable quantities (Delaplane and Mayer, 2000). Insects, such as bees and hoverflies, are the predominant pollination vectors for apple and thus their activity in orchards is essential for apple production (Klein et al., 2007). Increasing insect pollinator numbers in apple orchards has shown improved fruit set and yield (Kumar, 1997) and there is some evidence that levels of pollination affect seed number with associated impacts on size and calcium concentration (Matsumoto et al., 2012).

The vital role which honeybees play in the pollination of large number of cultivated crops is often under estimated in developing countries. As a matter of fact, the main significance of honeybees and beekeeping is pollination. Therefore, income from agriculture by the use of honeybees in crop pollination is many times higher than their value as honey and beeswax producers (Verma, 2003; Mattu, 2013). Honeybees are considered as the most efficient pollinators of cultivated crops because of their potential for long working hours, presence of pollen baskets, floral fidelity, micromanipulation of flowers, maintainability of high population and adaptability to different climatic conditions (Verma, 1990; Mattu and Mattu, 2013). Further, honeybees can be domesticated, marketed and transported from place to place (Crane, 1990; Mattu et al., 1996, 2006). In the absence of honeybee pollination, the important factors that lacked in the complex of agronomical practices in apple cultivation were the total cross-pollination and fertilization of flowers and this led to the flower as well as fruit drop and a higher fruit drop in Golden Delicious and Red Gold cultivars (Kolesnikov, 1972; Dulta and Verma, 1987; Mattu et al., 2012; Mattu, 2014) but pollination by Apis cerana enhanced increase in fruit setting and quality of fruit set in apple crop ( Mattu and Mattu, 2007).

\section{Methodology}

Quantitative and qualitative effects of honeybee pollination on apple crop were investigated on European bee, Apis mellifera $\mathrm{L}$. and Indian hive bee, Apis cerana F., by placing two colonies of each species in experimental apple orchards located at Padola (2200 m), Kalzar (2514 m) and Jarol (2648 m) areas in Shimla hills of Himachal Pradesh.

\subsection{Effect of Honeybee Pollination on Fruit Set}

The following experimental designs were set to study the effect of honeybee pollination on fruit set at the time of bloom in the apple orchards located at different altitudes. 


\section{International Journal of Science and Research (IJSR) \\ ISSN (Online): 2319-7064 \\ Index Copernicus Value (2013): 6.14 | Impact Factor (2015): 6.391}

2.1 (a) Experiment A (Honeybee pollinated flowers)

In honeybee pollinated flowers, four trees, one each of Golden Delicious, Red Gold, Royal Delicious and Red Delicious were enclosed in an insect proof net in which two colonies of honeybees (one of A. mellifera and one of $A$. cerana) were placed as pollinators of apple bloom. In this experiment, four branches of each variety, containing approximately eight hundred pink buds were chosen at random. These branches of experimental trees were chosen in such a way that they were of same dimensions with respect to their spread, phase of flowering and height above the ground. The bees were kept inside the net till the last flower on experimental trees. Fruit set was observed after ten days of petal fall and the percentage was measured as below:

Percentage of Fruit Set $=\frac{\text { Number of Fruits }}{\text { Number of Pink Buds }} \times 100$

2.1(b), Experiment B (Open, besides honeybees other natural insect pollinators were present)

In open pollinated flowers, honeybees and other natural insect pollinators could visit the apple flowers freely. In this experiment also, equal number of branches of ten experimental trees, two trees each of Golden Delicious and Red Gold and three trees each of Royal Delicious and Red Delicious were chosen in the same way as in case of honeybees pollinated experiment and each branch contained approximately eight hundred pink buds. The results were expressed in terms of percentages of fruit set and calculated as honeybee pollinated flowers.

\section{1(c) Experiment C (Control, where no insect pollinator was present)}

In control experiment ten trees, two each of self-compatible varieties (Golden Delicious, Red Gold) and three each of self-incompatible varieties (Royal Delicious and Red Delicious) were selected and in each tree four branches, each containing approximately five hundred flowers at pink bud stage were chosen at random and covered with muslin bags so that no insect pollinator could enter the bag for pollination. These branches of experimental trees were chosen in the same way as in case of honeybee pollinated experiment. Before covering with muslin bags, the numbers of pink buds were counted in each experimental branch. The fruit set was observed after ten days of the petal fall, calculated as honeybee pollinated flowers.

Similar experimental designs were set up in all the three orchards and the percentage of fruit set was calculated.

\subsection{Effect of honeybee pollination on fruit drop}

After calculating the fruit set in different experimental designs, the number of fruits dropped in the month of June, was also noted in different experimental designs i.e. open, honeybee pollinated and control. The fruit drop was observed from the ratio of fruits dropped to the total number of fruits set. This fruit drop was also calculated in terms of percentage (Dulta, 1986).

\subsection{Quality improvement in the apple fruit due to honeybee pollination}

Quality improvement in the fruit due to pollination was assessed in terms of increase in weight, length, breadth, volume and number of seeds per fruit. Weight of fruit in grams was measured with the help of a top pan electric balance; length and breadth in centimeter with the help of Vernier callipers; volume in $\mathrm{ml}$ on the line of the principle that the volume of an object is equal to the amount of water displaced by it. Finally, the number of seeds in a fruit was counted by cutting it. For each parameter, ten fruits were taken to get the mean values of weight, length, breadth, volume and number of seeds (Dulta, 1986; Kumar, 1997).

\section{Results and Discussion}

\subsection{Effect of insect pollinators on fruit set of apple}

In apple orchard at Padola $(2200 \mathrm{~m})$, self-compatible varieties like Golden Delicious and Red Gold, the fruit sets in control experiment were $17.53 \%$ and $15.74 \%$ respectively, whereas, in open pollinated flowers of Golden Delicious and Red Gold the fruit set was $20.77 \%$ and $17.91 \%$ respectively. In honeybees pollinated flowers, the fruit set in Golden Delicious and Red Gold were $31.33 \%$ and $23.69 \%$ respectively. However, in case of self-incompatible varieties of apple, such as Royal Delicious and Red Delicious, the role of honeybees in pollination was very significant. For example, the fruit set in Royal Delicious were $0 \%, 15.71 \%$ and $22.52 \%$ percent in control, open and honeybee pollinated flowers respectively. Similarly, at the same orchard, the fruit set in Red Delicious were $0 \%, 13.50 \%$ and $21.02 \%$ in control, open and honeybee pollinated flowers respectively (Table 1).

At Kalzar, (2514 m) in Golden Delicious, Red Gold, Royal Delicious and Red Delicious the fruit set in control experiment were $16.89 \%, 15.93 \%, 0 \%$ and $0 \%$ respectively. In open pollinated flowers fruit set were $18.51 \%, 16.33 \%$, $15.57 \%$ and $11.95 \%$ in Golden Delicious, Red Gold, Royal Delicious, Red Delicious respectively, whereas, in honeybees pollinated flowers the fruit set in Golden Delicious, Red Gold, Royal Delicious and Red Delicious were $29.74 \%, 22.82 \%, 21.61 \%$ and $20.51 \%$ respectively (Table 1).

In Golden Delicious, Red Gold, royal Delicious and Red Delicious the fruit set were $17.22 \%, 17.37 \%, 0 \%$ and $0 \%$ respectively in control experiment, whereas, the fruit set was $19.82 \%, 20.04 \%, 8.74 \%$ and $8.63 \%$ respectively in open pollinated flowers at Jarol $(2648 \mathrm{~m})$. Moreover, at the same height, the fruit set in honeybee pollinated flowers of Golden Delicious, Red Gold, Royal Delicious and Red Delicious was $22.58 \%, 21.71 \%, 17.39 \%$ and $16.62 \%$ respectively (Table 1). In self-compatible varieties of apple (Golden Delicious and Red Gold) there was no significant difference $(\mathrm{P}>0.01)$ in the fruit set in different experimental designs (honeybees pollinated flowers, open pollinated flowers and in control) but the differences in these experimental designs were significant $(\mathrm{P}<0.01)$ in self-incompatible varieties like Royal Delicious and Red Delicious.

\subsection{Effect of insect pollinators in apple fruit drop}

In the present study it has been found that fruit drop was significantly higher $(\mathrm{P}>0.01)$ in self-compatible varieties of apple under controlled experiment as compared to the fruits 


\section{International Journal of Science and Research (IJSR) \\ ISSN (Online): 2319-7064 \\ Index Copernicus Value (2013): 6.14 | Impact Factor (2015): 6.391}

from open and honeybees pollinated flowers. At Padola, Kalzar and Jarol in Golden Delicious, the fruit drops were maximum $(37.73 \%, 39.20 \%$ and $40.17 \%$ respectively) under control experiment and minimum $(25.74 \%, 27.21 \%$ and $28.92 \%$ respectively) in honeybee pollinated flowers. In open pollinated flowers of Golden Delicious, the fruit drops were $28.31 \%, 28.73 \%$ and $30.99 \%$ at Padola, Kalzar and Jarol respectively (Table 2). Similarly at Padola, Kalzar and Jarol in Red Gold, the fruit drops were maximum (37.33\%, $38.90 \%$ and $37.52 \%$ respectively) under control experiment and minimum $(24.69 \%, 26.47 \%$ and $28.27 \%$ respectively) in honeybee pollinated flowers. In open pollinated flowers of Red Gold, the fruit drops were $30.88 \%, 32.89 \%$ and $31.99 \%$ respectively. No significant difference $(\mathrm{P}>0.01)$ was observed in fruits drops of self-compatible varieties between open and honeybees pollinated flowers. In self-incompatible variety like Royal Delicious, the fruit drops in open pollinated flowers were $30.20 \%, 30.93 \%$ and $31.32 \%$ at Padola, Kalzar and Jarol respectively, whereas, in honeybees pollinated flowers the fruit drops were $26.20 \%, 26.47 \%$ and $27.58 \%$ respectively. In other self-incompatible variety of Red Delicious, the fruit drops in open pollinated flowers at Padola, Kalzar and Jarol were $30.36 \%, 29.99 \%$ and $31.47 \%$ respectively, whereas, in honeybees pollinated flowers of Red Delicious, the fruit drops were $25.04 \%, 26.81 \%$ and $28.20 \%$ respectively. The difference observed in the fruit drops of self-incompatible varieties between open and honeybees pollinated flowers was without any significant difference $(\mathrm{P}>0.01)$.

\subsection{Quality improvement in the apple fruits due to insect pollination}

Quality improvement in the apple fruit was observed in terms of increase in weight $(\mathrm{gm})$, length and breadth $(\mathrm{cm})$, volume $(\mathrm{ml})$ and number of seeds per fruit. In apple orchard at Padola, the mean weights of apple fruit in honeybee pollinated Golden Delicious, Red Gold, Royal Delicious and Red Delicious were $190.28 \pm 1.92 \mathrm{gm}, 195.16 \pm 3.12 \mathrm{gm}$, $188.66 \pm 3.24 \mathrm{gm}$ and $175.16 \pm 7.23 \mathrm{gm}$ respectively. Whereas, at Kalzar the mean weights in honeybees pollinated Golden Delicious, Red Gold, Royal Delicious and Red Delicious were $247.88 \pm 0.46 \mathrm{gm}, 206.75 \pm 1.25 \mathrm{gm}$, $347.83 \pm 2.92 \mathrm{gm}$ and $256.84 \pm 5.43$ gm respectively. At Jarol, the mean weights of Golden Delicious, Red Gold, Royal Delicious and Red Delicious in honeybee pollinated fruits were $195.56 \pm 1.90 \mathrm{gm}, 180.75 \pm 1.24 \mathrm{gm}, 266.16 \pm$ $2.12 \mathrm{gm}$ and $216.46 \pm 3.92 \mathrm{gm}$ respectively (Table 3 ).

The mean lengths of Golden Delicious, Red Gold, Royal Delicious and Red Delicious under this set of experiment at Padola were $8.53 \pm 0.40 \mathrm{~cm}, 7.68 \pm 0.04 \mathrm{~cm}, 8.16 \pm 0.42 \mathrm{~cm}$ and $7.17 \pm 0.54 \mathrm{~cm}$ respectively, while at Kalzar the mean lengths of Golden Delicious, Red Gold, Royal Delicious and Red Delicious were $8.16 \pm 0.17 \mathrm{~cm}, 7.99 \pm 0.10 \mathrm{~cm}, 10.66 \pm$ $0.38 \mathrm{~cm}$ and $8.17 \pm 0.43 \mathrm{~cm}$ respectively. The mean lengths of fruit in honeybees pollinated flowers of Golden Delicious, Red Gold, Royal Delicious and Red Delicious were $8.82 \pm$ $0.53 \mathrm{~cm}, 7.92 \pm 0.41 \mathrm{~cm}, 9.59 \pm 0.03 \mathrm{~cm}$ and $8.02 \pm 0.19 \mathrm{~cm}$ respectively at Jarol (Table 3 ).

In apple orchard at Padola, the mean breadths of Golden Delicious, Red Gold, Royal Delicious and Red Delicious in honeybee pollinated flowers were $8.39 \pm 0.23 \mathrm{~cm}, 7.84 \pm$ $0.14 \mathrm{~cm}, 8.49 \pm 0.53 \mathrm{~cm}$ and $8.54 \pm 0.23 \mathrm{~cm}$ respectively. The mean breadths of Golden Delicious, Red Gold, Royal Delicious and Red Delicious in Honeybees pollinated flowers were $8.91 \pm 0.04 \mathrm{~cm}, 8.75 \pm 0.09 \mathrm{~cm}, 9.74 \pm 0.24$ $\mathrm{cm}$ and $9.03 \pm 0.92 \mathrm{~cm}$ respectively at Kalzar, whereas, the mean breadths were $8.84 \pm 0.02 \mathrm{~cm}, 8.02 \pm 0.14 \mathrm{~cm}, 9.21 \pm$ $0.03 \mathrm{~cm}$, and $8.46 \pm 0.06 \mathrm{~cm}$, in Golden delicious, Red Gold, Royal Delicious and Red Delicious respectively at Jarol. The mean volumes of Golden delicious, Red Gold, Royal delicious and Red Delicious were $161.88 \pm 3.13 \mathrm{ml}, 171.29$ $\pm 4.82 \mathrm{ml}, 165.29 \pm 3.75 \mathrm{ml}$ and $140.58 \pm 8.20 \mathrm{ml}$ respectively at Padola, whereas, $281.50 \pm 3.26 \mathrm{ml}, 200.88 \pm$ $2.35 \mathrm{ml}, 417.02 \pm 3.51 \mathrm{ml}$ and $242.59 \pm 13.25 \mathrm{ml}$ respectively at Kalzar and $173.96 \pm 1.92 \mathrm{ml}, 154.59 \pm 1.85$ $\mathrm{ml}, 230.04 \pm 2.05 \mathrm{ml}$ and $177.50 \pm 2.97 \mathrm{ml}$ respectively at Jarol (Table 3).

At Padola, the mean number of seeds per fruit in honeybee pollinated flowers of Golden Delicious, Red Gold, Royal Delicious and Red Delicious were $7.24 \pm 0.10,7.80 \pm 0.10$, $6.8 \pm 0.10$ and $6.44 \pm 0.10$ respectively whereas, the mean number of seeds per fruit were $10.29 \pm 0.38,11.29 \pm 2.05$, $8.89 \pm 0.67$ and $8.29 \pm 1.67$, respectively at Kalzar and these were $10.20 \pm 0.87,10.89 \pm 1.05,8.62 \pm 0.92$ and $8.29 \pm 1.02$ respectively at Jarol (Table 3 ).

In self-incompatible varieties like Royal Delicious and Red Delicious there was not any fruit set in control experiment but in self-compatible varieties like Golden Delicious and Red Gold the quality of apple fruit was noticed. It was noticed that weight, length, breadth, volume and number of seeds per fruit in Golden Delicious and Red Gold at all the three orchards were significantly maximum $(\mathrm{P}<0.01)$ in fruits which developed from honeybees pollinated flowers and minimum in fruits under control experimental conditions, whereas, in Royal Delicious and Red Delicious the weight, length, breadth, volume and number of seeds per fruit were significantly more $(\mathrm{P}<0.01)$ in fruits from honeybees pollinated flowers than in fruits from open pollinated flowers.

In honeybee pollinated flowers the fruits were larger in size than fruits from open pollinated flowers which were in turn larger than the fruits from control experiment. Observations on fruit quality were made by some earlier workers (Singh, 1962; Morse, 1976) who reported that honeybee pollination increased quality and quantity of apple fruits. The better pollinating efficiency of honeybees help in the fertilization of maximum number of ovules and thereby more number of seeds are formed in this way maximum amount of auxin (a growth hormone) is produced which results in better size of fruits. Fruits obtained by self pollination had a lower average weight, size and poor colour and contained a small number of seeds as compared to the fruits obtained from cross pollination (Murneek and Schowengerdt, 1935). It was reported that greater number of seeds depended upon greater number of bees involved in cross pollination (4). There was positive relation between honeybee pollination and quality of apple crop (Dulta, 1986; Sihag, 1997; Belavadi et al., 2005). Fruit set in peach (Prunus persica L.) was maximum (6.5 fruit/branch) with placement of honeybee colonies at the closet distance of $20 \mathrm{~m} \mathrm{(5).} \mathrm{Similar} \mathrm{results} \mathrm{on} \mathrm{fruit} \mathrm{quality}$ 


\section{International Journal of Science and Research (IJSR) \\ ISSN (Online): 2319-7064 \\ Index Copernicus Value (2013): 6.14 | Impact Factor (2015): 6.391}

and yield due to honeybee pollination was also observed in different crops (Potts et al., 2010b; Raj et al., 2012).
The authors are thankful to the Chairman, Department of Biosciences, Himachal Pradesh University, Shimla for providing the necessary facilities and for encouragements.

\section{Acknowledgement}

Table 1: Percentage of fruit set in three different experimental designs

\begin{tabular}{|c|c|c|c|c|c|c|c|c|c|c|}
\hline \multirow[b]{2}{*}{ Sr. No. } & \multirow[b]{2}{*}{ Variety } & \multicolumn{3}{|c|}{ Padola (2200 m) } & \multicolumn{3}{|c|}{ Kalzar (2514 m) } & \multicolumn{3}{|c|}{ Jarol (2648 m) } \\
\hline & & $\begin{array}{c}\text { Honeybees } \\
\text { pollinated } \\
\text { flowers } \\
(\mathrm{H})\end{array}$ & $\begin{array}{c}\text { Open } \\
\text { pollinated } \\
\text { flowers } \\
(\mathrm{O})\end{array}$ & $\begin{array}{c}\text { No insect } \\
\text { pollinator } \\
\text { (Control) } \\
\text { (C) }\end{array}$ & $\begin{array}{c}\text { Honeybees } \\
\text { pollinated } \\
\text { flowers } \\
(\mathrm{H})\end{array}$ & $\begin{array}{c}\text { Open } \\
\text { pollinated } \\
\text { flowers } \\
(\mathrm{O})\end{array}$ & $\begin{array}{c}\text { No insect } \\
\text { pollinator } \\
\text { (Control) } \\
\text { (C) }\end{array}$ & $\begin{array}{l}\text { Honeybees } \\
\text { pollinated } \\
\text { flowers } \\
(\mathrm{H})\end{array}$ & $\begin{array}{c}\text { Open } \\
\text { pollinated } \\
\text { flowers } \\
(\mathrm{O})\end{array}$ & $\begin{array}{c}\text { No insect } \\
\text { pollinator } \\
\text { (Control) } \\
\text { (C) }\end{array}$ \\
\hline 1. & Golden delicious & 31.33 & 20.77 & 17.53 & 29.74 & 18.51 & 16.89 & 22.58 & 19.82 & 17.92 \\
\hline 2. & Red Gold & 23.69 & 17.91 & 15.74 & 22.82 & 16.33 & 15.93 & 21.71 & 20.04 & 17.37 \\
\hline 3. & Royal Delicious & 22.52 & 15.71 & 0 & 21.61 & 15.57 & 0 & 17.39 & 8.74 & 0 \\
\hline 4. & Red Delicious & 21.02 & 13.50 & 0 & 20.51 & 11.95 & 0 & 16.62 & 8.63 & 0 \\
\hline
\end{tabular}

For honeybee pollination two colonies, one Apis mellifera and one Apis cerana with 6 frames each were placed inside the net.
Each percentage is an average of twelve observations. S.E. = Standard error about the mean.

Table 2: Percentage of fruit drop in three different experimental designs

\begin{tabular}{|c|c|c|c|c|c|c|c|c|c|c|}
\hline \multirow[b]{2}{*}{$\begin{array}{l}\text { Sr. } \\
\text { No. }\end{array}$} & \multirow[b]{2}{*}{ Variety } & \multicolumn{3}{|c|}{ Padola $(2200 \mathrm{~m})$} & \multicolumn{3}{|c|}{ Kalzar $(2514$ m) } & \multicolumn{3}{|c|}{ Jarol (2648 m) } \\
\hline & & $\begin{array}{c}\text { Honeybees } \\
\text { pollinated } \\
\text { flowers } \\
(\mathrm{H})\end{array}$ & \begin{tabular}{|c|} 
Open \\
pollinated \\
flowers \\
$(\mathrm{O})$
\end{tabular} & $\begin{array}{c}\text { No insect } \\
\text { pollinator } \\
(\text { Control) } \\
(\mathrm{C})\end{array}$ & $\begin{array}{l}\text { Honeybees } \\
\text { pollinated } \\
\text { flowers } \\
(\mathrm{H})\end{array}$ & $\begin{array}{c}\text { Open } \\
\text { pollinated } \\
\text { flowers } \\
(\mathrm{O})\end{array}$ & $\begin{array}{l}\text { No insect } \\
\text { pollinator } \\
\text { (Control) } \\
\text { (C) }\end{array}$ & $\begin{array}{l}\text { Honeybees } \\
\text { pollinated } \\
\text { flowers } \\
(\mathrm{H})\end{array}$ & $\begin{array}{c}\text { Open } \\
\text { pollinated } \\
\text { flowers } \\
(\mathrm{O})\end{array}$ & $\begin{array}{l}\text { No insect } \\
\text { pollinator } \\
\text { (Control) } \\
\text { (C) }\end{array}$ \\
\hline 1. & 1 & 25.74 & 28.31 & 37.73 & 27.21 & 28.73 & 39.20 & 28.92 & 30.99 & 40.17 \\
\hline 2. & Red Gold & 24.69 & 30.88 & 37.33 & 26.47 & 32.89 & 38.90 & 28.27 & 31.99 & 37.52 \\
\hline 3. & Royal Deliciou & 26.20 & 30.20 & 0 & 26.47 & 30.93 & 0 & 27.58 & 31.32 & 0 \\
\hline 4. & Red Delicious & 25.04 & 30.36 & 0 & 26.81 & 29.99 & 0 & 28.20 & 31.47 & 0 \\
\hline
\end{tabular}

For honeybee pollination two colonies, one Apis mellifera and one Apis cerana with 6 frames each were placed inside the net.
Each percentage is an average of twelve observations.

S.E. $=$ Standard error about the mean.

For fruit drop: $\mathrm{H}<\mathrm{O}<\mathrm{C}(\mathrm{P}<0.01)$.

Table 3: Effect of insect pollinators on the quality of apple fruit in terms of weight (gm), length (cm), breadth (cm), volume (ml) and number of seeds per fruit

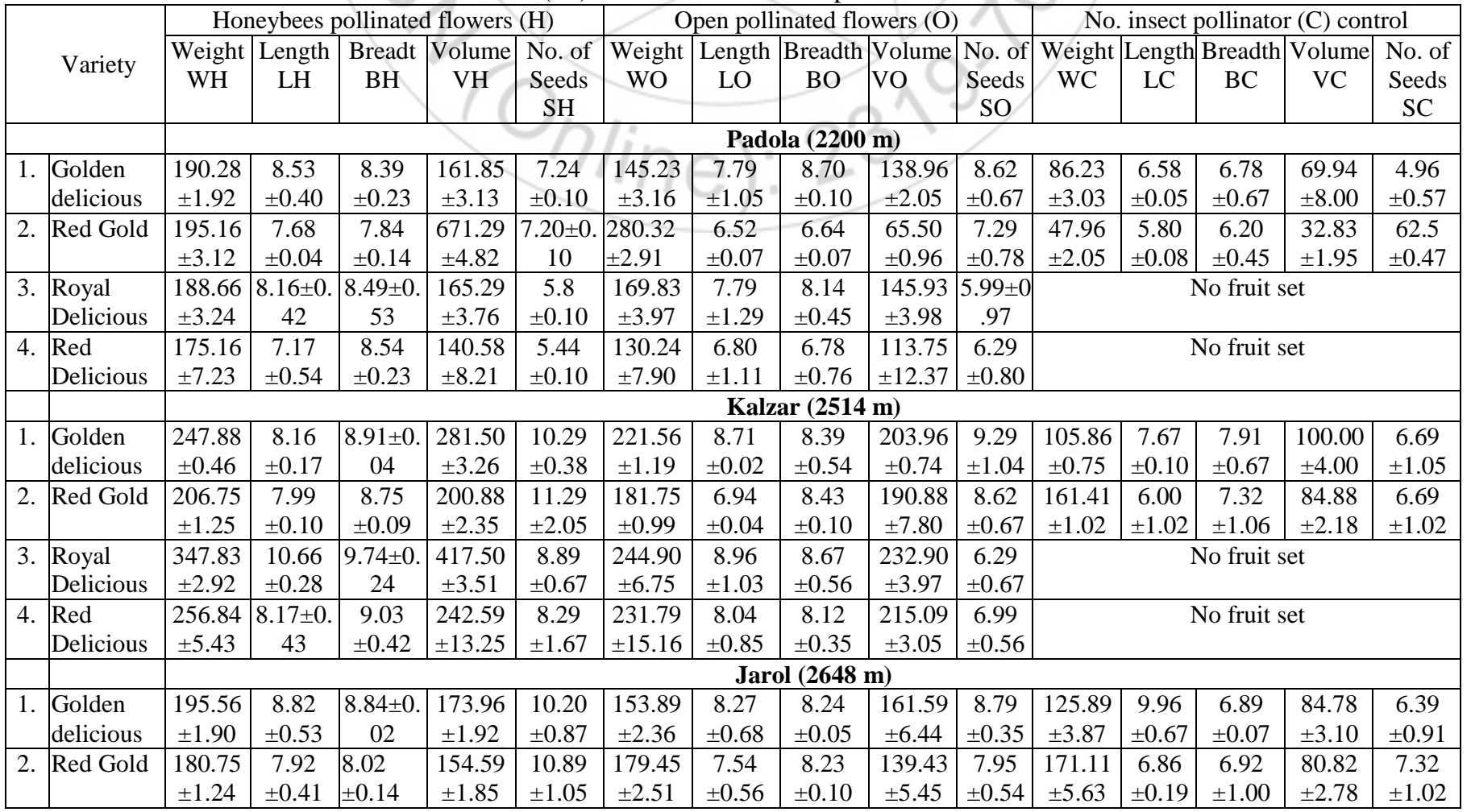


International Journal of Science and Research (IJSR)

ISSN (Online): 2319-7064

Index Copernicus Value (2013): 6.14 | Impact Factor (2015): 6.391

\begin{tabular}{|l|l|c|c|c|c|c|c|c|c|c|c|c|}
\hline 3. & Royal & 266.16 & $9.59 \pm 0$. & 9.21 & 230.04 & 8.62 & 25.192 & 7.65 & 8.59 & 159.26 & 6.29 & \\
& Delicious & \pm 2.12 & 03 & \pm 0.03 & \pm 2.05 & \pm 0.92 & \pm 6.46 & \pm 0.45 & \pm 0.25 & \pm 3.05 & \pm 0.64 & \\
\hline 4. & Red & 216.46 & 8.07 & 8.46 & 177.50 & 8.29 & 193.79 & 8.42 & 8.26 & 154.59 & 6.36 & \\
& Delicious & \pm 3.92 & \pm 0.19 & \pm 0.06 & \pm 2.97 & \pm 1.02 & \pm 4.54 & \pm 0.56 & \pm 0.19 & \pm 6.54 & \pm 0.89 & \\
\hline
\end{tabular}

For honeybee pollination two colonies, one Apis mellifera and one Apis cerana with 6 frames each were placed inside the net.

Each percentage is an average of twelve observations.

S.E. $=$ Standard error about the mean.

In all the orchards:

$1 \mathrm{~W}(\mathrm{H})>1 \mathrm{~W}(\mathrm{O})>1 \mathrm{~W}(\mathrm{C}): 1 \mathrm{~L}(\mathrm{H})>1 \mathrm{~L}(\mathrm{O})>1 \mathrm{~L}(\mathrm{C}): 1 \mathrm{~B}(\mathrm{H})$

$>1 \mathrm{~B}(\mathrm{O})>1 \mathrm{~B}(\mathrm{C}): 1 \mathrm{~V}(\mathrm{H})>1 \mathrm{~V}(\mathrm{O})>1 \mathrm{~V}(\mathrm{C} 0: 1 \mathrm{~S}(\mathrm{H})>$

$1 \mathrm{~S}(\mathrm{O} 0>1 \mathrm{~S}(\mathrm{C})(\mathrm{P}<0.01)$

$2 \mathrm{~W}(\mathrm{H})>2(\mathrm{~W}) \mathrm{O}>2 \mathrm{~W}(\mathrm{C}): 2 \mathrm{~L}(\mathrm{H})>2 \mathrm{~L}(\mathrm{O})>2 \mathrm{~L}(\mathrm{C}): 2 \mathrm{~B}(\mathrm{H})$

$>2 \mathrm{~B}(\mathrm{O})>2 \mathrm{~B}(\mathrm{C}): 2 \mathrm{~V}(\mathrm{H})>2 \mathrm{~V}(\mathrm{O})>2 \mathrm{~V}(\mathrm{C}): 2 \mathrm{~S}(\mathrm{H})>2 \mathrm{~S}(\mathrm{O})$

$>2 \mathrm{~S}(\mathrm{C})(\mathrm{P}<0.01)$

$3 \mathrm{~W}(\mathrm{H})>3 \mathrm{~W}(\mathrm{O}) \quad: 3 \mathrm{~L}(\mathrm{H})>3 \mathrm{~L}(\mathrm{O}): 3 \mathrm{~B}(\mathrm{H})>3 \mathrm{~B}(\mathrm{O}):$

$3 \mathrm{~V}(\mathrm{H})>3 \mathrm{~V}(\mathrm{O}): 3 \mathrm{~S}(\mathrm{H})>3 \mathrm{~S}(\mathrm{C})(\mathrm{P}<0.01)$

$4 \mathrm{~W}(\mathrm{H})>4 \mathrm{~W}(\mathrm{O}) \quad: 4 \mathrm{~L}(\mathrm{H})>4 \mathrm{~L}(\mathrm{O}): 4 \mathrm{~B}(\mathrm{H})>4 \mathrm{~B}(\mathrm{O})$

$4 \mathrm{~V}(\mathrm{H})>4 \mathrm{~V}(\mathrm{O}): 4 \mathrm{~S}(\mathrm{H})>4 \mathrm{~S}(\mathrm{C})(\mathrm{P}<0.01)$

\section{References}

[1] Abson, D.J., Termansen, M., (2011). Valuing ecosystem services in terms of ecological risks and returns. Conservation Biology 25, 250-258.

[2] Belavadi, V.V., Anwarulla, M.S., Shadakshari, Y.G. and Dinesh Kumar, M. (2005). Rice research in the hill zone of Karnataka (Zone 9). In: Five decades of Rice Research in Karnataka (Eds.: Prabhakara Setty, T.K., Purushotham, S. and Nagamani, M.K.), Directorate of Research, UAS, Bangalore, 82-89.

[3] Biesmeijer, J.C., Roberts, S.P.M., Reemer, M., Ohlemüller, R., Edwards, M., Peeters, T., Schaffers, A.P., Potts, S.G., Kleukers, R., Thomas, C.D., Settele, J. and Kunin, W.E. (2006). Parallel Declines in Pollinators and Insect-Pollinated Plants in Britain and the Netherlands. Science 313 (5785): 351-354.

[4] Bornus, L., Zamarlicki, C., Krol, S. and Jablonski, B. (1977). Influence of increased bee visitation to apple flowers on fruit size and yield. Pszczelnicze Zesz. Nauk. 21: 77-86

[5] Chaudhry, O. P. (2008). Influence of Different colony placement distances on yield and quality parameters of peach (Prunus persica L.). Korean Journal of Apiculture, 23 (2): 89-95.

[6] Childers, N.F. (1976). Flower bud formation, pollination and fruit set in the apple. In: Modern fruit science (Ed.: Childres, N.F.). Horticultural Publications, Rutgers University, N.J. 128-145.

[7] Crane, E. (1990). Bees and Beekeeping-Science, Practice and World resources. Heineman Newners, Oxford.

[8] Delaplane, K.S., Mayer, N.F. (2000). Crop Pollination by Bees. CABI Publishing, Walling-ford.

[9] Dulta, P. C. (1986). Comparative morphometric and biochemical studies on flight muscles of genus Apis and its role in apple pollination. Ph.D. Thesis H.P. University Shimla-5.
[10]Dulta, P. C. and Verma, L.R. (1987). Role of insect pollinators on yield and quality of apple fruit. Indian $\mathrm{J}$. Hortic. 44: 274-279.

[11]FAOStat,(2013).Crops.http://faostat.fao.org/site/567/De sktopDefault.aspx ?PageID= 567\#ancor.

[12] Gallai, N., Salles, J.M., Settele, J. and Vaissiere, B.E. (2009). Economic valuation of the vulnerability of world agriculture confronted with pollinator decline, Ecological Economics, 68: 810 - 821.

[13] Klein, A.M., Vaissiere, B.E., Cane, J.H., SteffanDewenter, I., Cunningham, S.A., and Kremen, C. (2007). Importance of pollinators in changing landscapes for world crops. Proc. R. Soc. Lon. B. Biol. Sci. 274: 303-313.

[14] Kolesnikov, V.A. (1972). Role of honeybees as pollinators in orchards. In: pollination of entomophilous agricultural crops by bees (Ed.: Kozin, R.B.). Amrind Pub. Co. Ltd., New York.

[15] Kozin, R.B. (1972). Pollination of entomophilous crops by bees. Amrind Pub. Co. Pvt. Ltd., New York.

[16] Kumar, L. (1997). Foraging ecology and behaviour of Apis cerana $\mathrm{F}$. and Apis mellifera $\mathrm{L}$. in pollinating apple and cherry flowers. Ph.D Thesis, Himachal Pradesh University, Shimla, India.

[17]Ladurner, E., Recla, L., Wolf, M., Zelger, R., Burgio, G. (2004). Osmia cornuta (Hymenoptera Megachilidae) densities required for apple pollination: a cagestudy. Journal of Apicultural Research 43, 118-122.

[18] Matsumoto, S., Soejima, J., Maejima, T. (2012). Influence of repeated pollinationon seed number and fruit shape of 'Fuji' apples. Scientia Horticulturae 137,131-137.

[19] Mattu, N., Sharma, R.M., Mattu, V.K. and Sharma, M. 2006. Diversity, Abundance and Foraging Activity of insect Pollinators on Pyrus communis Linn. In: Biodiversity and Environment (Eds.: Pandey B.N. and Kulkarni G.K.). A.P.H. Pub., New Delhi, 13-28.

[20]Mattu, V.K. 2013. Pollinator Friendly Management Practices in Himachal Himalayas. In "Vignettes of Himachal Himalayas- Vol 2". Satyam Publishing House, New Delhi, pp 75-99.

[21] Mattu, V.K. 2014. Role of honeybees and other pollinators in crop productivity and impacts of climate change. Wkshp. on Promotion of Honey Beekeeping in Haryana, Panchkula, pp. 56-74.

[22] Mattu, V.K. and Mattu, N. 2003. Pollinator-Pesticide Interaction in Mountain Agro-Ecosystem. In "Pollination Ecology, Biodiversity, Food and Nutritional Security" (ed.: Raju, A.J.S.). Andhra University, Visakhapatnam, 130-136.

[23] Mattu, V.K. and Mattu, N. 2007. Conservation and Management of Pollinators for Sustainable Horticulture in Himachal Himalaya. Institute of Integrated Himalayan Studies (UGC Centre of Excellence), HP Univ., Shimla. 128 pages.

[24] Mattu, V.K. and Mattu, N. 2013. Mountain perspectives and modern Beekeeping Technology. Himalayan Studies Journal 4: 103-114. 


\section{International Journal of Science and Research (IJSR) \\ ISSN (Online): 2319-7064}

Index Copernicus Value (2013): 6.14 | Impact Factor (2015): 6.391

[25] Mattu, V.K., Hem Raj \& Thakur, M.L. 2012. Foraging behavior of honeybees on apple crop and its variation with altitude in Shimla Hills of Western Himalaya, India. International Journal of Science and Nature 3(1): 296-301.

[26] Mattu, V.K., Sharma, N., Kumar, D. and Kumar, L. 1996. Pollination Ecology of Stone Fruit Crops in Himachal Pradesh, India. Rec. Adv. Biosc. \& Ocean., 75-88.

[27] Morse, R.A. (1976). Efficient use of honeybees in the orchard. Proc. Annu. Meet. N.Y. Hortic. Soc. 1021: 6164.

[28] Murneek, A.E. and Schowengerdt, G.C. (1935). A study of the relation of size of apples to number of seeds and weight of the spur leaves. Proc. Am. Soc. Hort. Sci. 33: 4-6.

[29] Potts, S.G., Biesmeijer, J.C., Kremen, C., Neumann, P., Schweiger, O. and Kunin, W.E. (2010 a). Global pollinator declines: trends, impacts and drivers. Trends in Ecology and Evolution 25, 345-353.

[30] Potts, S.G., Roberts, S.P.M., Dean, R., Marris, G., Brown, M., Jones, R. and Settele, J. (2010 b). Declines of managed honey bees and beekeepers in Europe. Journal of Apicultural Research 49: 15-22. DOI: 10.3896/IBRA.1.49.1.02.

[31] Raj, H., Mattu, V.K. and Thakur, M.L. 2012. Pollinator diversity and relative abundance of insect visitors on apple crop in Shimla hills of western Himalaya, India. International Journal of Science and Nature 3 (3): 507513.

[32] Rana, R.S., Sharma, H.K., Rana, K. and Rana, B.S. (2010). Studies on Apis mellifera L. pollination in apple and its economics. Proc. Nat. Sym. Persp. Challng. Integ. Pest Manag. Sustian. Agric. Solan, 100.

[33] Sihag, R.C. (1997). Pollination Biology: Basic and Applied Principles. Rajendra Scientific Publishers, Hisar, 213 pp.

[34] Singh, S. (1962). Beekeeping in India (Ed.: S. Singh). Indian Coun. Agric. Res., New Delhi.

[35] Tscharntke, T. (2007). Importance of pollinators in changing landscapes for world crops. Proceedings of the Royal Society B: Biological Sciences 274,303-313.

[36] Verma, L.R. (1990). Beekeeping in integrated mountain development: Economic and Scientific perspectives. Oxford and IBH Pub. Co. Ltd. New Delhi.

[37] Verma, L.R. (2003). Conservation and management of Asian Hive bee Apis cerana. Asian Bee J. 5 ( $1 \& 2)$ : 110. 